Article

\title{
Design and Experimental Study on a New Closed-Cycle Desalination System Based on Ambient Temperature
}

\author{
Jun Liu ${ }^{1}$, Yong Sun ${ }^{2}$, Sanjiang $\mathrm{Yv}^{2}$, Jiaquan Wang ${ }^{3, *(D)}$ and Kaixuan $\mathrm{Hu}^{1}$ \\ 1 School of Civil Engineering, Hefei University of Technology, Hefei 230009, China; \\ jun-liu@mail.hfut.edu.cn (J.L.); hkx1994091066 @163.com (K.H.) \\ 2 Anhui Tongsu Environment Protection Technology Co Ltd., Hefei 230009, China; ly200704@163.com (Y.S.); \\ yy736@163.com (S.Y.) \\ 3 School of Resources and Environmental Engineering, Hefei University of Technology, Hefei 230009, China \\ * Correspondence: jiaquan.wang@163.com or wangjiaquan@hfut.edu.cn
}

Received: 7 August 2020; Accepted: 9 September 2020; Published: 10 September 2020

\begin{abstract}
The use of seawater desalination technology to solve water shortages in energy- and resource-scarce regions has attracted widespread attention worldwide. In this paper, the performance of a closed-cycle humidification-dehumidification desalination system with a heat pump was experimentally investigated. The system is a closed-cycle system, which includes humidifiers, a heat pump, dehumidifiers, and an air heat exchanger. The heat pump is used by the system to carry energy. The effects of different parameters on the system performance were studied. Scale and economic analyses of the system were conducted to explore the application prospects of the system. The maximum gained output ratio of the system was 4.82. The maximum freshwater production was $960 \mathrm{~kg} / \mathrm{h}$, and the cost per kilogram of freshwater was USD 0.03, which are more considerable compared with other systems. This system provides an effective way to save energy in remote areas with energy shortages and freshwater resource shortages.
\end{abstract}

Keywords: humidification-dehumidification (HDH); closed-cycle system; heat pump

\section{Introduction}

The world economy has developed rapidly, the scale of industrial activities has continued to increase, and the population has accelerated, resulting in global water shortages [1]. By consuming the least amount of energy to produce freshwater, desalination systems can play a significant role in areas where water resources are scarce.

Traditional desalination methods include MED (multi-effect distillation), MSF (multi-stage flash evaporation), VC (vapor compression), RO (reverse osmosis), ED (electrodialysis) [1], solar distillation [2], and nanofiltration, which usually require high construction costs and large amounts of fossil fuels [1]. HDH (humidification-dehumidification) desalination technology is a promising option to ensure the safe supply of freshwater in regions with scarce water resources [3]. In the humidifier, moist air is humidified by vaporized seawater, then it flows into the dehumidifier, condenses, and discharges freshwater [4]. An HDH desalination plant has the advantages of convenient maintenance, small footprint, long service life, and excellent compatibility with renewable energy [5]. $\mathrm{HDH}$ technology has been proven to be an inexpensive and reliable desalination system [6].

The heat source of $\mathrm{HDH}$ systems in many studies is mainly from solar radiation. Many scholars have performed numerous different studies on the application of solar energy in $\mathrm{HDH}$ desalination plants.

The design of the solar HDH systems needs to be improved in order to improve the efficiency and economy of the system according to the studies conducted by Abdelmoez et al. [7], 
and Sathyamurthy et al. [8]. Zamen et al. [9] optimized the performance of the HDH desalination process through mathematical programming but increased the cost. Liu et al. [10] and Zubair et al. [11] studied solar-based HDH desalination systems, and their results show that the performance of the system is greatly affected by solar radiation.

In addition to solar power plants, heat pump units can also effectively provide heat for HDH systems and provide cooling for hot and humid air condensation. Compared with the traditional HDH system, studies on the use of heat pump technology in HDH are lacking.

$\mathrm{Xu}$ et al. [12] constructed a system combining a heat pump with humidification-dehumidification $(\mathrm{HDH})$ and established mathematical models to improve system performance. He et al. [13], Faegh et al. [14], Wu et al. [15], Lawal et al. [16], and Zhang et al. [17] conducted a series of experiments and numerical studies on the system combining a heat pump and HDH. The influence of different operating parameters on the system was studied.

A new compact closed-cycle HDH desalination system, with the following features, is experimentally studied in this paper:

- The entire system is in a closed state. Compared with other systems, this system uses a more compact structure, which can make full use of the energy and can minimize heat loss.

- The system is designed with an air heat exchanger, which can recover more heat.

- The flow of air is opposite to that of seawater, which improves the heat and mass transfer efficiency of the humidifier.

- The system only needs to consume electricity, does not need to consume steam, and is not affected by solar radiation.

The different parameters of the system are studied, including the temperature of seawater entering the humidifier $\left(\mathrm{T}_{\mathrm{s} 1}\right)$, the flow rate of seawater entering the humidifier $\left(\mathrm{f}_{\mathrm{s} 1}\right)$, and the air flow rate in the plant $\left(\mathrm{F}_{\mathrm{a} 4}\right)$. On this basis, the maximum production efficiency, humidifier efficiency, the gained output ratio, and economic cost are studied and compared with other HDH systems.

This system provides a better method for the popularization of desalination technology in remote areas with energy shortages and freshwater resource shortages.

\section{Materials and Methods}

The system included humidifiers, a heat pump, dehumidifiers, and an air heat exchanger. Figures 1 and 2 show the schematic and a detailed view of the system. The entire system was in a closed state, including air circulation, seawater circulation, and refrigerant circulation.

Air circulation: The air is initially heated in the air heat exchanger. A fan blows air into the humidifier from the bottom. The air is heated again in the humidifier. In the humidifier, the air carries water vapor formed by the evaporation of seawater. The air enters the air heat exchanger after forming saturated air. Then, the air enters the dehumidifier. In the dehumidifier, air transfers heat to the refrigerant. The air from the dehumidifier re-enters the air heat exchanger.

In the air heat exchanger, saturated air transfers a part of the heat to the air blown out by the dehumidifier, which improves the sensible heat of the air blown out by the dehumidifier. The freshwater is produced in air heat exchangers and dehumidifiers.

Figure 3 shows the air humidity diagram under an experimental condition-the air circulation process in the system. A1, A2, A3, and A4 represent the air conditions at the humidifier outlet, dehumidifier inlet, dehumidifier outlet, and humidifier inlet, respectively.

Seawater circulation: Seawater is pumped into the circulation tank. Seawater is sprayed onto the titanium pipes (condenser of the heat pump) through the circulation pump in the humidifier. A large amount of water is vapor formed by the endothermic evaporation of seawater. Water vapor is carried by air into the air heat exchanger. The remaining seawater returns to the circulation tank. 
Refrigerant circulation: The humidifier is combined with the condenser of the heat pump and the dehumidifier is combined with the evaporator of the heat pump. The refrigerant absorbs energy in the dehumidifier and releases energy in the humidifier.

In the air heat exchanger, a system cooling module is designed. When the system runs for too long, causing heat build-up, the module will cool the system. The module also has a dehumidifying effect.

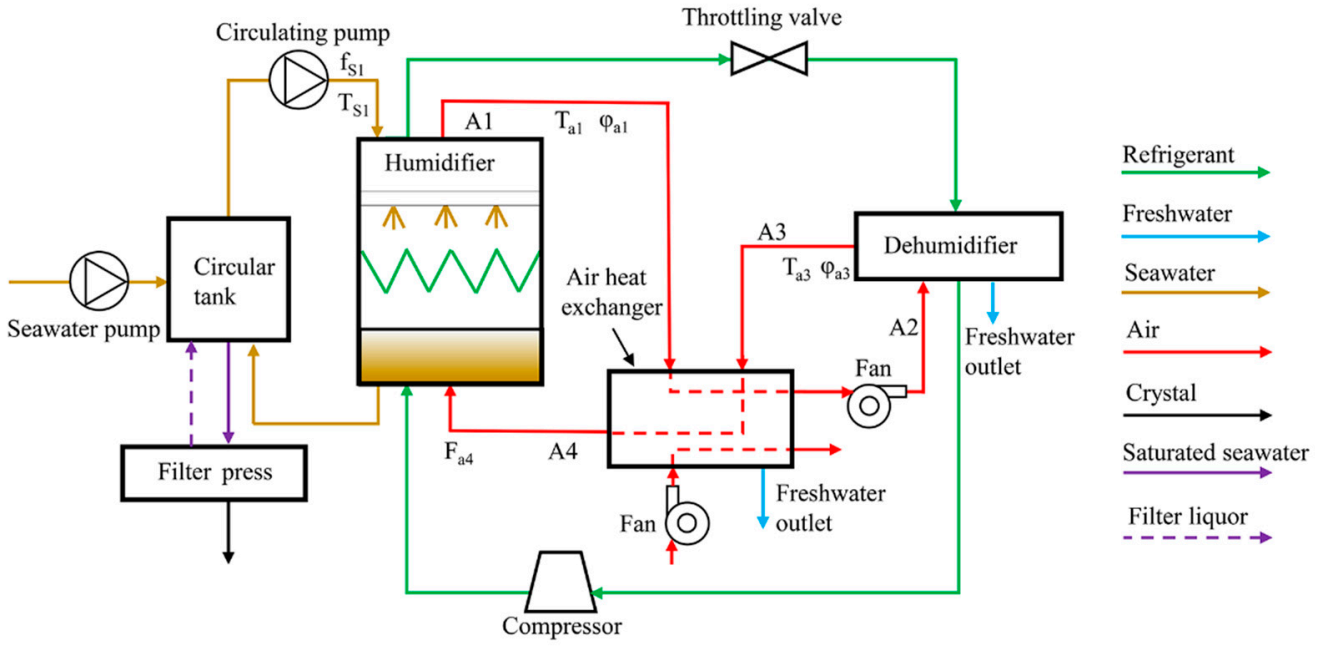

Figure 1. Schematic drawing of experimental set-up.

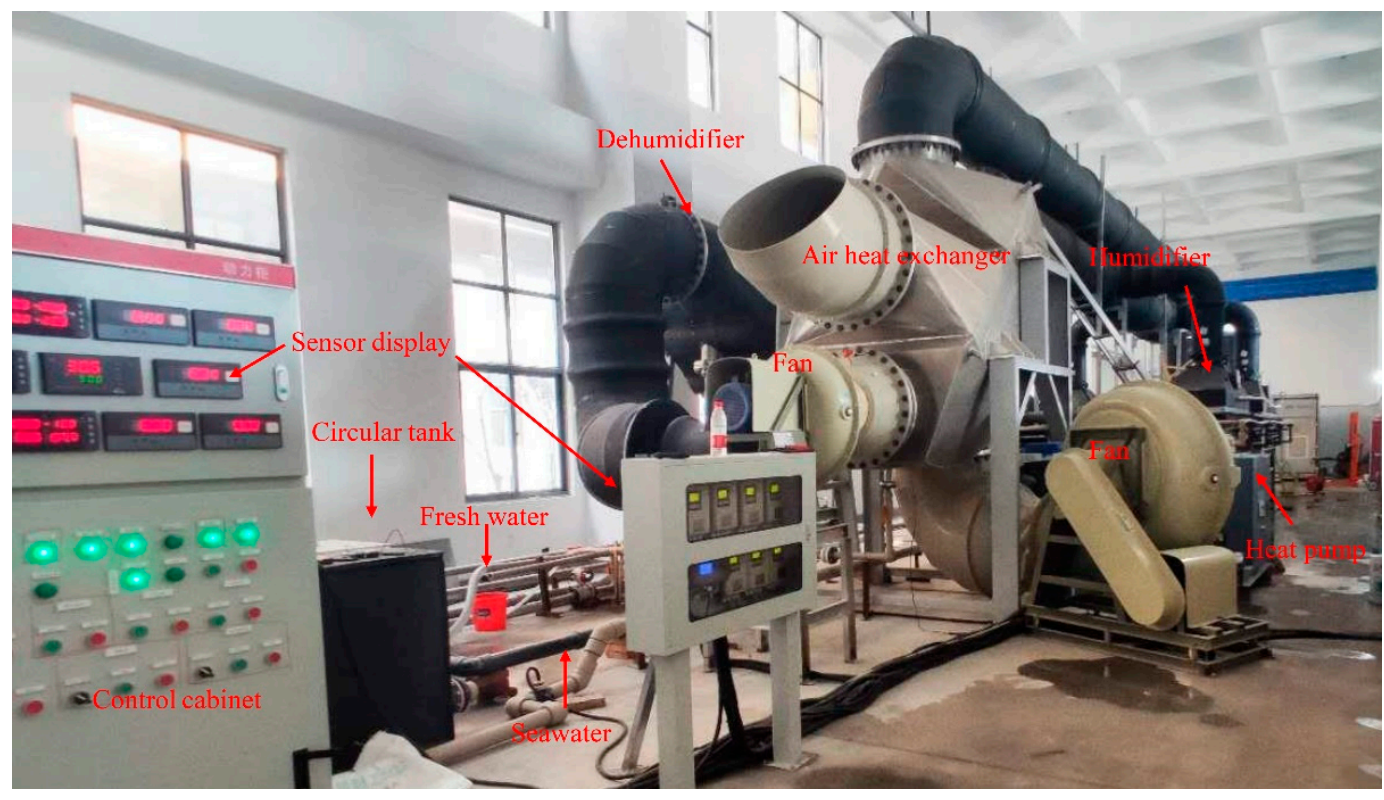

Figure 2. Photo of the experiment plant of the system. 


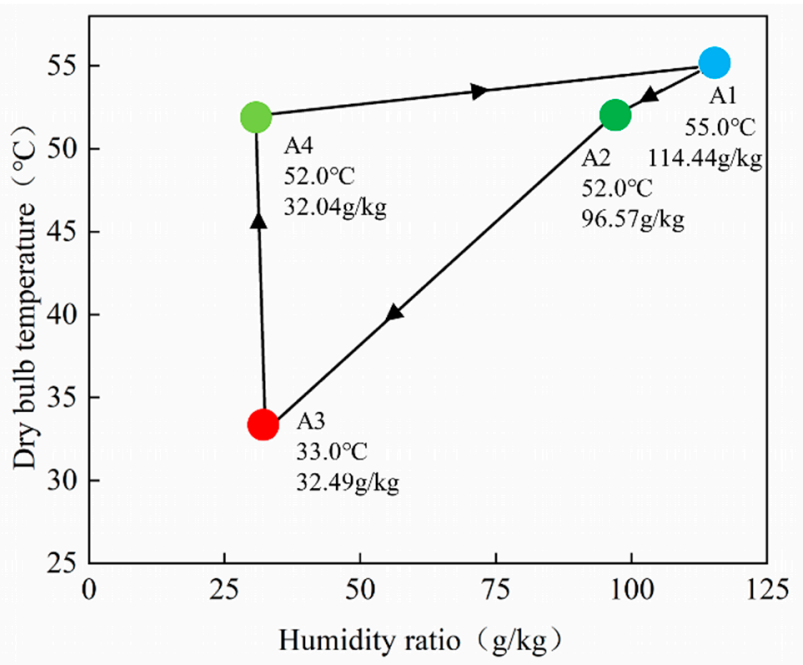

Figure 3. Psychometric chart of the proposed humidification-dehumidification (HDH) process.

\subsection{Humidifier}

The system contained two sets of humidifiers. The humidifier consisted of five parts-namely the upper cover, the bottom funnel, the spray pipes and titanium pipes, and the shell. Spray pipes were arranged in the upper part of the inner chamber, which was ringed with seawater. Titanium pipes were arranged in the middle, which was ringed with refrigerant.

\subsection{Heat Pump}

In the heat pump, the humidifier is the condenser of the heat pump, and the dehumidifier is the evaporator. The theoretical COP (coefficient of performance) of the heat pump was 5.6, and the refrigerant model used in the refrigerant cycle of the system was R134a. The theoretical input power of this heat pump was $92 \mathrm{KW}$.

\subsection{Air Heat Exchanger}

The air heat exchanger was composed of aluminum material, and the air duct material was polypropylene. The diameter of the air ducts entering the air heat exchanger was $80 \mathrm{~cm}$, and the diameter of the two outlet air ducts of the air heat exchanger was $60 \mathrm{~cm}$. In the air heat exchanger, the total heat transfer area was $100 \mathrm{~m}^{2}$.

In the system cooling module, the heat transfer area was $80 \mathrm{~m}^{2}$.

\subsection{Dehumidifier}

The structure of the dehumidifier was the same as that of the air heat exchanger, but the dimensions were different. The diameter of the refrigerant pipes was $20 \mathrm{~cm}$, which was made of copper. The diameter of the air duct was $60 \mathrm{~cm}$. The heat transfer area was $115 \mathrm{~m}^{2}$.

\subsection{Circulation Tank}

The circulating tank material was made of polypropylene with a thickness of $8 \mathrm{~mm}$. The volume of the circulating tank was $5 \mathrm{~m}^{3}$. The outside of the circulation tank was wrapped with thermal insulation material. A liquid level gauge was introduced to control the entry of external seawater.

\subsection{Pumps and Fans}

The power of seawater circulation was controlled by a $1.5 \mathrm{KW}$ frequency conversion pump, and the inlet water of the circulation tank was controlled by a $0.75 \mathrm{KW}$ frequency conversion pump. 
The air circulation was controlled by a variable frequency fan with a power of $11 \mathrm{KW}$. A frequency conversion fan was introduced to control the air dehumidification and heat dissipation module.

\subsection{Air Ducts, Water Pipes, and Refrigerant Pipes}

The air ducts and water pipes were made of $5 \mathrm{~mm}$ thick polypropylene. The material of the refrigerant pipe was titanium.

\subsection{Other Instruments}

Anemometers, thermohygrometers, thermal resistances, and ultrasonic flowmeters were used to monitor and record different indicators. Table 1 records the relevant parameters of the instruments.

Table 1. Relevant parameters of the instruments.

\begin{tabular}{ccccc}
\hline Instrument & Parameter & Range & Accuracy & Error \\
\hline Anemometer & Air velocity & $0.2-20 \mathrm{~m} / \mathrm{h}$ & $0.01 \mathrm{~m} / \mathrm{h}$ & $\pm 3 \%$ \\
Thermohygrometer & Temperature & $-40 \sim 70{ }^{\circ} \mathrm{C}$ & $0.1{ }^{\circ} \mathrm{C}$ & $\pm 0.6^{\circ} \mathrm{C}$ \\
Thermal resistance & Relative humidity & $0 \sim 100 \%$ & $0.1 \%$ & $\pm 0.1 \%$ \\
Ultrasonic flowmeter & Temperature & $-50 \sim 100{ }^{\circ} \mathrm{C}$ & $0.1{ }^{\circ} \mathrm{C}$ & $\pm 0.5^{\circ} \mathrm{C}$ \\
\hline
\end{tabular}

\section{Results and Discussions}

The experiment studied the different parameters of the system. The optimal operating conditions of the system were studied. This paper studied three input parameters, including the temperature of seawater entering the humidifier $\left(\mathrm{T}_{\mathrm{s} 1}\right)$, the flow rate of seawater entering the humidifier $\left(\mathrm{f}_{\mathrm{s} 1}\right)$, and the air flow rate in the plant $\left(\mathrm{F}_{\mathrm{a} 4}\right)$. The best overall performance was obtained. The GOR (gained output ratio), under the optimal working condition of the system, was studied. The feasibility and economics of the system were summarized and compared.

\subsection{Seawater Temperature}

Fixed parameters: $F_{a 4}=12,000 \mathrm{~m}^{3} / \mathrm{h}$, and $\mathrm{f}_{\mathrm{s} 1}=32 \mathrm{~m}^{3} / \mathrm{h}$.

The temperature of the seawater $\left(\mathrm{T}_{\mathrm{s} 1}\right)$ in the circulation tank was controlled by a thermostat. In the experiment, $\mathrm{T}_{\mathrm{s} 1}$ varied between 44 and 52 degrees Celsius. Freshwater productivity is shown in Figure 4. Freshwater production increased from $550 \mathrm{~kg} / \mathrm{h}$ to $960 \mathrm{~kg} / \mathrm{h}$. It can be seen from Figure 5 that $\mathrm{T}_{\mathrm{a} 1}, \mathrm{~T}_{\mathrm{a} 3}, \varphi_{\mathrm{a} 1}$, and $\varphi_{\mathrm{a} 3}$ all increase with the increase in $\mathrm{T}_{\mathrm{s} 1}$. In the dehumidifier, with the increase in $\mathrm{T}_{\mathrm{s} 1}$, the temperature difference between $\mathrm{T}_{\mathrm{a} 1}$ and $\mathrm{T}_{\mathrm{a} 3}$ changed slightly. The heat exchange efficiency of the dehumidifier did not vary greatly. However, with the increase in $\varphi_{\mathrm{a} 1}$ and $\varphi_{\mathrm{a} 3}$, the enthalpy difference between the air at the outlet of the humidifier and the outlet of the dehumidifier continued to increase, which is the main reason for the increase in productivity. $T_{\mathrm{s} 1}$ and $\mathrm{T}_{\mathrm{a} 1}$ also affected the heating capacity and condensing capacity of the heat pump unit. With the increase in $\mathrm{T}_{\mathrm{s} 1}$ and $\mathrm{T}_{\mathrm{a} 1}$, the heat capacity and cold capacity of the heat pump unit increased. Saturated air with a higher temperature and humidity ratio entering the dehumidifier can result in a greater yield of freshwater. The total productivity increases with the increase in $\mathrm{T}_{\mathrm{s} 1}$. $\mathrm{T}_{\mathrm{s} 1}$ increased from 42 to $52^{\circ} \mathrm{C}$, and freshwater productivity increased by $75 \%$. Therefore, the temperature of the seawater had an obvious impact on productivity. 


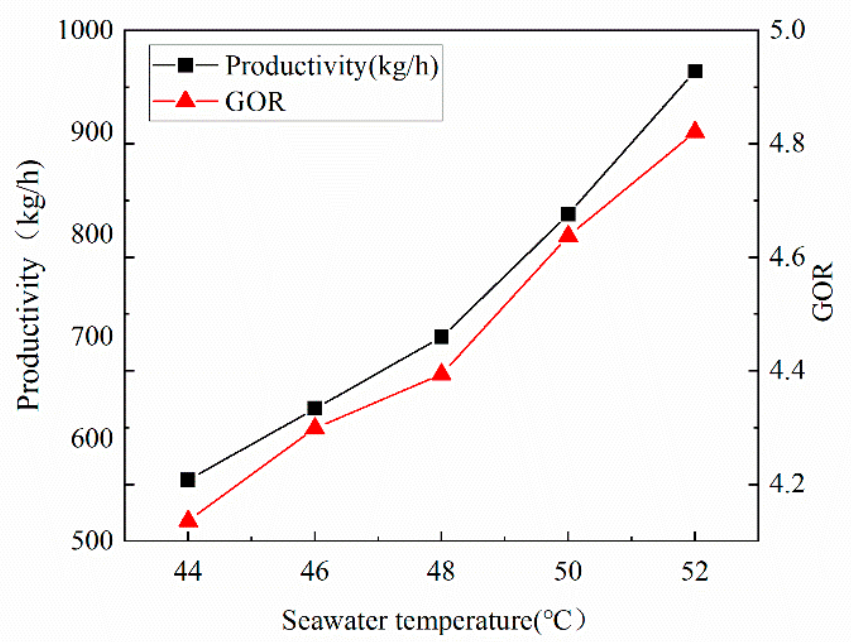

Figure 4. Effect of seawater temperature on system productivity and gained output ratio (GOR).

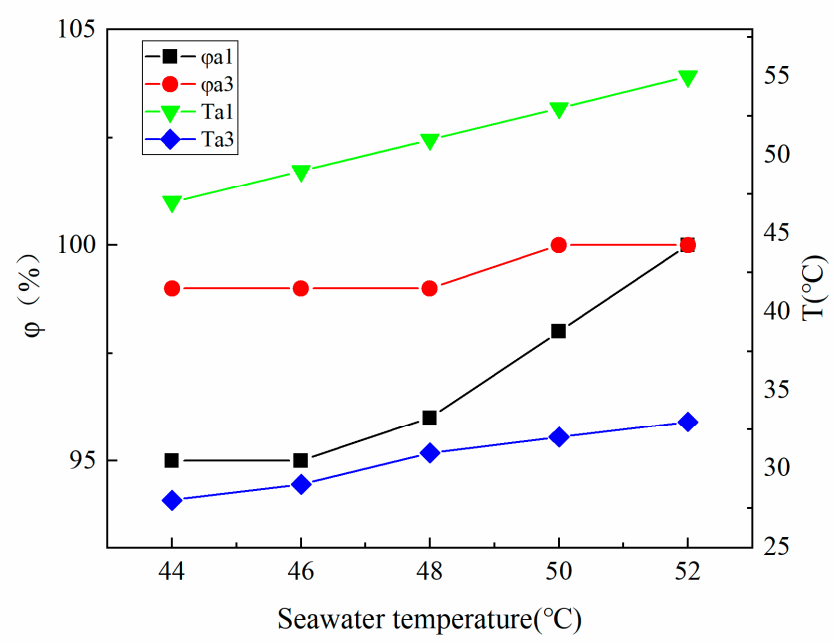

Figure 5. Effect of seawater temperature on relative humidity and air temperature.

\subsection{Air Flow Rate}

Fixed parameters: $\mathrm{T}_{\mathrm{s} 1}=52{ }^{\circ} \mathrm{C}, \mathrm{f}_{\mathrm{s} 1}=32 \mathrm{~m}^{3} / \mathrm{h}$.

A fan that could control the speed by adjusting the voltage was introduced to control the air flow rate $\left(\mathrm{F}_{\mathrm{a} 4}\right)$. As $\mathrm{F}_{\mathrm{a} 4}$ increased, as shown in Figure 6, there was a change in freshwater productivity. Figure 7 describes the changes in $\mathrm{T}_{\mathrm{a} 1}, \mathrm{~T}_{\mathrm{a} 3}, \varphi_{\mathrm{a} 1}$, and $\varphi_{\mathrm{a} 3}$. It can be seen from Figure 6 that when $\mathrm{T}_{\mathrm{s} 1}$ and $\mathrm{f}_{\mathrm{s} 1}$ were unchanged, as $\mathrm{F}_{\mathrm{a} 4}$ increased, $\mathrm{T}_{\mathrm{a} 1}$ and $\mathrm{T}_{\mathrm{a} 3}$ both had a downward trend. With the increase in $\mathrm{F}_{\mathrm{a} 4}$, both $\varphi_{\mathrm{a} 1}$ and $\varphi_{\mathrm{a} 3}$ were relatively stable. When $\mathrm{F}_{\mathrm{a} 4}$ increased to a specific value, $\varphi_{\mathrm{a} 1}$ decreased. The air temperature and relative air humidity changed in the opposite direction to $\mathrm{F}_{\mathrm{a} 4}$. This shows that, with the increase in $\mathrm{F}_{\mathrm{a} 4}$, the heat loss in the dehumidifier was smaller, and the heat exchange efficiency also increased. Due to the reduction in heat loss in the dehumidifier and the increase in $\mathrm{F}_{\mathrm{a} 4}$, the combined effect of the two led to an upward trend in the freshwater production rate. In the process of increasing the air flow rate from $8000 \mathrm{~m}^{3} / \mathrm{h}$ to $13,000 \mathrm{~m}^{3} / \mathrm{h}$, the air flow rate increased by $63 \%$, and the freshwater productivity increased by $12 \%$. The productivity of freshwater increased slightly. Therefore, freshwater productivity is not sensitive to changes in air flow rate. 


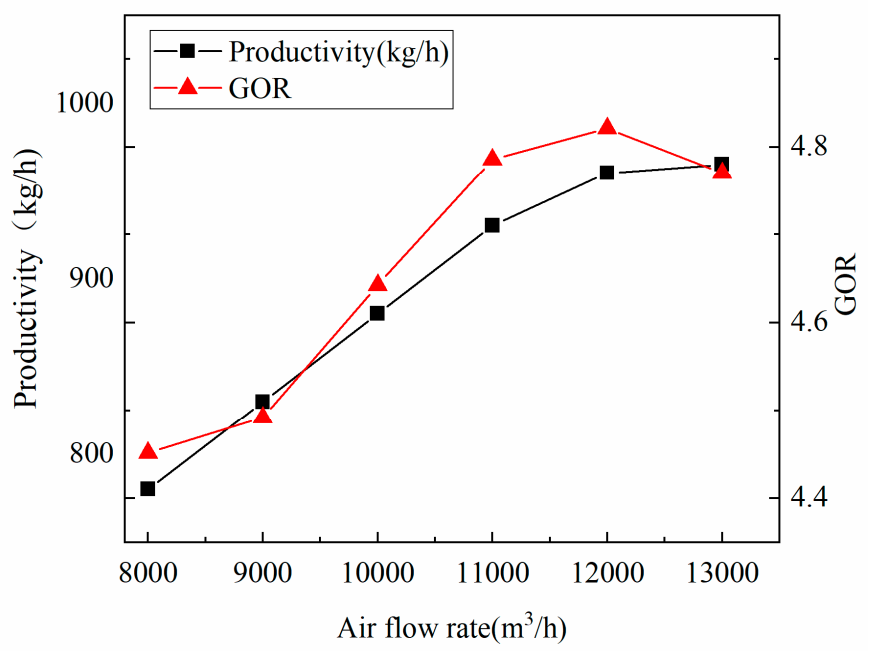

Figure 6. Effect of air flow rate on system productivity and GOR.

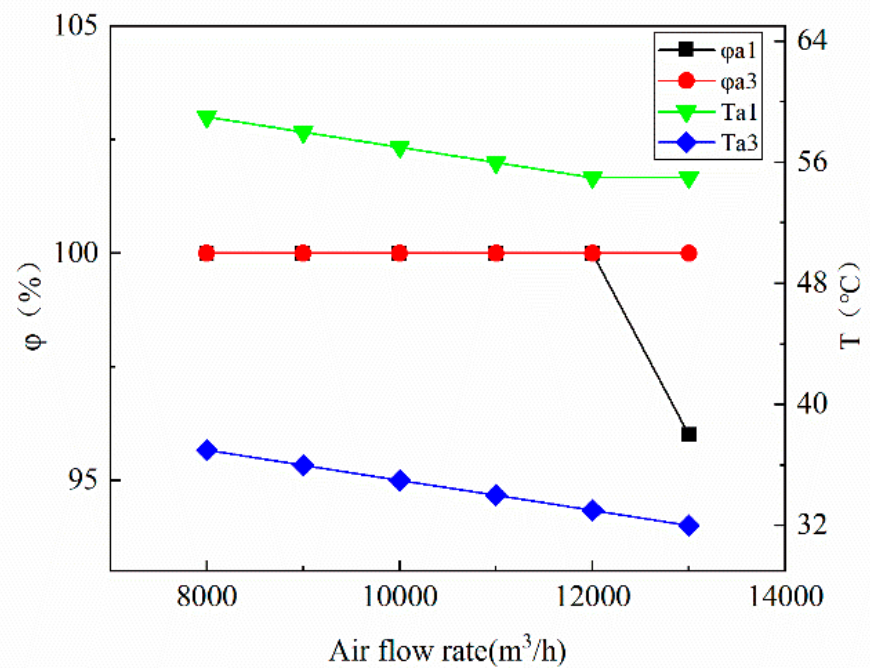

Figure 7. Effect of air flow rate on air humidity and air temperature.

\subsection{Seawater Flow Rate}

Fixed parameters: $\mathrm{F}_{\mathrm{a} 4}=12,000 \mathrm{~m}^{3} / \mathrm{h}, \mathrm{T}_{\mathrm{s} 1}=52^{\circ} \mathrm{C}$.

The $\mathrm{f}_{\mathrm{s} 1}$ was controlled by a water pump. In the experiment, $\mathrm{f}_{\mathrm{s} 1}$ varied from $28 \mathrm{~m}^{3} / \mathrm{h}$ to $36 \mathrm{~m}^{3} / \mathrm{h}$. The effect of $f_{s 1}$ on the system's freshwater productivity is shown in Figure 8. It can be seen that, with the increase in $f_{s 1}$, freshwater productivity continued to increase. When $f_{s 1}$ reached a specific value, the freshwater productivity remained stable. Figure 9 describes the changes in $T_{a 1}, T_{a}, \varphi_{a 1}$, and $\varphi_{\mathrm{a} 3}$. When $\mathrm{T}_{\mathrm{s} 1}$ and $\mathrm{F}_{\mathrm{a} 4}$ remained unchanged, with the increase in $\mathrm{f}_{\mathrm{s} 1}$, there was little change in $\mathrm{T}_{\mathrm{a} 1}, \mathrm{~T}_{\mathrm{a} 3}$, and $\varphi_{\mathrm{a} 3}$, while $\varphi_{\mathrm{a} 1}$ was consistent with the changing trend of system productivity. The heat exchange efficiency of the dehumidifier did not vary greatly. The increase in $\varphi_{\mathrm{a} 1}$ led to an increase in air enthalpy and specific humidity, thereby increasing the freshwater productivity of the system.

During the change in seawater flow rate, when the seawater flow rate increased from $28 \mathrm{~m}^{3} / \mathrm{h}$ to $32 \mathrm{~m}^{3} / \mathrm{h}$, the freshwater productivity increased from 800 to $960 \mathrm{~kg} / \mathrm{h}$. The seawater flow rate increased by $14 \%$ and the freshwater productivity increased by $20 \%$. However, when the seawater flow rate was greater than $32 \mathrm{~m}^{3} / \mathrm{h}$, the increase in the seawater flow rate had less impact on freshwater productivity and was affected by the heat exchange efficiency. Within a certain range, seawater flow had a greater impact on freshwater productivity. 


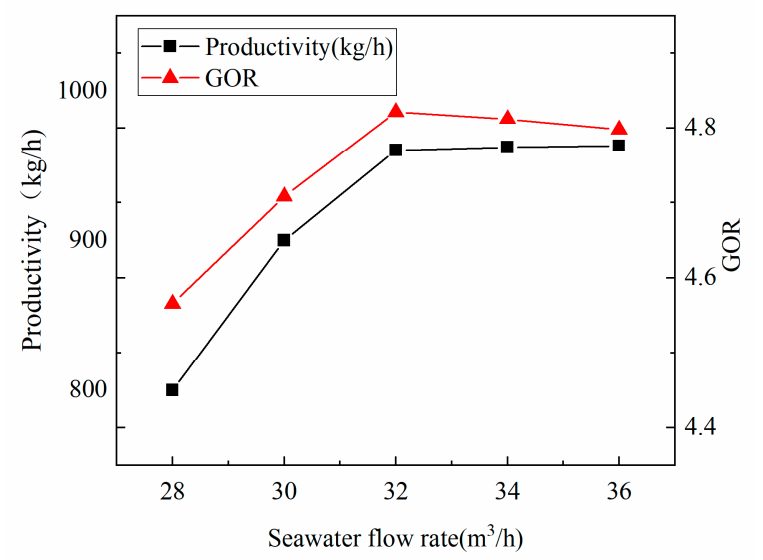

Figure 8. Effect of seawater flow rate on system productivity and GOR.

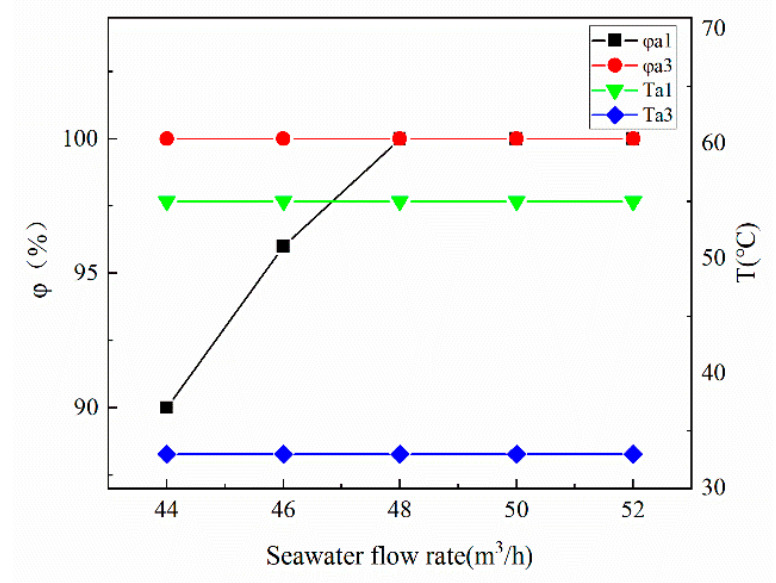

Figure 9. Effect of seawater flow rate on air humidity.

\subsection{System Productivity Evaluation}

\subsubsection{Humidification Performance}

Humidifier performance can be calculated using the following formula [18]:

$$
\varepsilon=100 \times \frac{Z_{\text {hum,out }}-Z_{\text {hum,in }}}{Z_{\text {hum,out-sat }}-Z_{\text {hum,in }}}
$$

In all test scenarios, when the optimal conditions were reached, the humidity at the measured humidifier outlet reached saturation. Therefore, the humidifier efficiency of the proposed system was $100 \%$.

\subsubsection{System Production Efficiency}

In this system, when the operating conditions were seawater temperature, air flow rate, and seawater flow rate at $52{ }^{\circ} \mathrm{C}, 12,000 \mathrm{~m}^{3} / \mathrm{h}$, and $32 \mathrm{~m}^{3} / \mathrm{h}$, the maximum productivity of the system was $960 \mathrm{~kg} / \mathrm{h}$. The compressor reached the best working condition when evaporator pressure was $0.5 \mathrm{MPa}$ and the condenser pressure was $16 \mathrm{MPa}$. Compared with the work of other researchers, the productivity was significantly improved.

\subsection{Performance Comparison with Different HDH Desalination Systems}

The general index for evaluating the performance of seawater desalination systems is GOR. The following expression can calculate GOR [19]: 


$$
G O R=\frac{m_{f} \times l}{w_{a}}
$$

During the experiments, the power of electrical appliances, such as fans, water circulation pumps, cold water circulation pumps, seawater pumps, and heat pumps, were measured. Figures 4, 6 and 8 show the change in GOR under different conditions. In this experiment, seawater temperature has a significant influence on GOR. Air flow rate and seawater flow rate have relatively little influence on GOR. After analysis of this experiment, the maximum value of GOR was 4.82.

Table 2 lists some reported performance parameters of other desalination systems. The freshwater productivity per unit of time of the proposed system is greater than most desalination systems, and the production cost is highly competitive. The proposed system saves energy and improves production efficiency.

Table 2. Comparison of different systems.

\begin{tabular}{ccccc}
\hline Researchers & Heat Source & Maximum Productivity & GOR & Cost of Freshwater \\
\hline Liu et al. [10] & Solar & $2.138 \mathrm{~kg} /\left(\mathrm{h} \cdot \mathrm{m}^{2}\right)$ & 2.5 & - \\
Zubair et al. [11] & Solar & $19,445 \mathrm{~kg} / \mathrm{year}$ & 2.6 & $0.032 \mathrm{US} \$ / \mathrm{kg}$ \\
Wu et al. [15] & Solar & $182 \mathrm{~kg} / \mathrm{h}$ & 2.65 & $0.0025 \mathrm{US} \$ / \mathrm{kg}$ \\
Mohamed et al. [20] & Solar & $2.45 \mathrm{~kg} / \mathrm{h}$ & - & $0.047 \mathrm{US} \$ / \mathrm{kg}$ \\
Zhao et al. [21] & Solar & $63 \mathrm{~kg} / \mathrm{h}$ & - & - \\
Rahimi et al. [22] & Solar & $1.07 \mathrm{~kg} /\left(\mathrm{h} \cdot \mathrm{m}^{2}\right)$ & 3.43 & - \\
Behnam et al. [23] & Solar & $6.275 \mathrm{~kg} /\left(\mathrm{day} \cdot \mathrm{m}^{2}\right)$ & - & $0.028 \mathrm{US} \$ / \mathrm{kg}$ \\
Xu et al. [12] & Solar assisted heat pump & $20.54 \mathrm{~kg} / \mathrm{h}$ & 2.42 & - \\
Shafii et al. [1] & Heat pump & $2.79 \mathrm{~kg} / \mathrm{h}$ & 2.08 & $0.0114 \mathrm{US} \$ / \mathrm{kg}$ \\
He et al. [13] & Heat pump & $82.12 \mathrm{~kg} / \mathrm{h}$ & 5.14 & - \\
Lawal et al. [16] & Heat pump & $287.8 \mathrm{~kg} / \mathrm{day}$ & 4.07 & $0.02 \mathrm{US} \$ / \mathrm{kg}$ \\
Zhang et al. [17] & Heat pump & $22.26 \mathrm{~kg} / \mathrm{h}$ & 2.052 & $0.051 \mathrm{US} \$ / \mathrm{kg}$ \\
Current study & Heat pump & $960 \mathrm{~kg} / \mathrm{h}$ & 4.82 & $0.03 \mathrm{US} \$ / \mathrm{kg}$ \\
\hline
\end{tabular}

\subsection{Cost Estimate}

Through cost estimation, the critical value of the system can be more intuitively reflected. Table 3 shows the cost of the system.

Table 3. Cost of the system.

\begin{tabular}{cc}
\hline Component & USD \\
\hline Heat pump & 17,142 \\
Fans & 1978 \\
Pumps & 1427 \\
Circulation tank & 428 \\
Humidifier & 13,428 \\
Air heat exchanger & 8857 \\
Second & 7428 \\
dehumidifier & 5714 \\
Ducts and pipes & 56,428 \\
Total cost (P) & \\
\hline
\end{tabular}

The operating life (n) of the system is assumed to be ten years. The system operating time ( $\mathrm{t}$ ) is assumed to be $20 \mathrm{~h}$ per day. The electricity cost (e) is $0.127 \mathrm{US} \$ / \mathrm{KWh}$ [17]. Through the calculation of the following formula, the cost per kilogram of fresh water can be obtained [24], which is shown in Table 4.

$$
\begin{aligned}
C R F & =\frac{i(1+i)^{n}}{(1+i)^{n}-1} \\
S & =0.2 \times P \\
S F F & =\frac{i}{(1+i)^{n}-1}
\end{aligned}
$$




$$
\begin{gathered}
F A C=P \times C R F \\
A M C=15 \% \times F A C \\
A S V=S \times S F F \\
A R C=365 t \times W \times e \\
A C=F A C+A M C+A R C-A S V \\
C=\frac{A C}{365 t n \times m_{f}}
\end{gathered}
$$

Table 4. Freshwater cost calculation.

\begin{tabular}{ccc}
\hline Parameter & Unit & Value \\
\hline $\mathrm{P}$ & US\$ & 56,429 \\
$\mathrm{n}$ & Year & 10 \\
$\mathrm{~S}$ & $\mathrm{US} \$$ & 11,285 \\
$\mathrm{i}$ & $\%$ & 12 \\
$\mathrm{~W}$ & $\mathrm{KW}$ & 125 \\
$\mathrm{e}$ & US\$/KWh & 0.127 \\
$\mathrm{t}$ & $\mathrm{h}$ & 20 \\
$\mathrm{CRF}$ & - & 14.74 \\
$\mathrm{SFF}$ & - & 0.057 \\
FAC & US\$ & 832,253 \\
ASV & US\$ & 643.11 \\
$\mathrm{AMC}$ & US\$ & 124,838 \\
ARC & US\$ & 246,375 \\
$\mathrm{AC}$ & US\$ & $1,202,806$ \\
$\mathrm{C}$ & US $\mathbf{k g}$ & 0.03 \\
\hline
\end{tabular}

The cost per kilogram of freshwater is USD 0.03. Compared with other systems in terms of energy and capacity, the system has certain advantages and competitiveness.

\section{Conclusions}

A new closed-cycle HDH desalination system was established. The effects of different parameters on the system performance were studied. The GOR of the system was studied. The system was economically evaluated, and the feasibility of the system studied was analyzed. Our conclusions are as follows:

- The condenser of the heat pump was combined with the humidifier, and the evaporator of the heat pump was combined with the dehumidifier. This design reduces energy consumption during heat exchange.

- The maximum freshwater production is $960 \mathrm{~kg} / \mathrm{h}$. This system used a heat pump, which did not need to absorb heat from too much radiation and can be used in areas with limited resources. This shows that the system can guarantee the production of fresh water and is not affected by environmental conditions.

- The temperature of the seawater has an obvious impact on productivity.

- As the air flow rate increases, the freshwater productivity will reach a maximum. As a result, the freshwater productivity will not be sensitive to changes in air flow rate.

- Within a certain range, freshwater productivity reaches a maximum value under a certain seawater flow rate, and seawater flow has a greater impact on freshwater productivity.

- The efficiency of the humidifier obtained by this system is $100 \%$. The gained output ratio of performance is 4.82. Compared to other HDH systems, this system requires less energy per unit of freshwater.

- The cost of freshwater per kilogram is approximately USD 0.03. The economy of this system is considerable. The proposed system saves energy and improves production efficiency. 
- The air ducts and water pipes of the system cause a certain amount of heat loss. It is very important to design a more compact system structure. The system can be designed in a container, which is convenient for industrial production and convenient for transportation.

Author Contributions: Conceptualization, J.W. and Y.S.; methodology, J.L. and K.H.; software, S.Y.; validation, J.L. and Y.S.; formal analysis, J.L. and K.H.; investigation, J.L.; resources, Y.S.; data curation, J.L.; writing-original draft preparation, J.L. and K.H.; writing-review and editing, J.W.; visualization, J.W.; supervision, J.W.; project administration, J.W. and Y.S.; funding acquisition, J.W. and Y.S. All authors have read and agreed to the published version of the manuscript.

Funding: This research received no external funding.

Acknowledgments: The authors acknowledge the support and funds received from Anhui Tongsu Environment Protection Technology Co., Ltd.

Conflicts of Interest: The authors declare no conflict of interest.

\section{Nomenclature}

\begin{tabular}{|c|c|}
\hline MED & Multi-effect distillation \\
\hline MSF & Multi-stage flash evaporation \\
\hline $\mathrm{VC}$ & Vapor compression \\
\hline $\mathrm{RO}$ & Reverse osmosis \\
\hline ED & Electrodialysis \\
\hline$\varphi$ & Air relative humidity, $\%$ \\
\hline $\mathrm{T}$ & Temperature, ${ }^{\circ} \mathrm{C}$ \\
\hline $\mathrm{F}$ & Air flow rate, $\mathrm{m}^{3} / \mathrm{h}$ \\
\hline $\mathrm{f}$ & Seawater flow rate, $\mathrm{m}^{3} / \mathrm{h}$ \\
\hline s1 & Seawater at the inlet of the humidifier \\
\hline a1 & Air at the outlet of the humidifiers \\
\hline a2 & Air at the outlet of the second dehumidifier \\
\hline a3 & Air at the inlet of the humidifiers \\
\hline$\varepsilon$ & Humidifier performance \\
\hline Z & Specific humidity, kgw/kga \\
\hline $\max$ & Maximum \\
\hline sat & Saturation \\
\hline GOR & Gained output ratio \\
\hline $\mathrm{m}_{\mathrm{f}}$ & Freshwater productivity, $\mathrm{kg} / \mathrm{h}$ \\
\hline 1 & Latent heat of vaporization, $\mathrm{kJ} / \mathrm{kg}$ \\
\hline $\mathrm{w}_{\mathrm{a}}$ & Electricity power, KW \\
\hline $\mathrm{P}$ & Total cost \\
\hline S & Salvage value \\
\hline $\mathrm{n}$ & Life \\
\hline $\mathrm{i}$ & Interest rate \\
\hline CRF & Capital recovery factor \\
\hline SFF & Sink fund factor \\
\hline FAC & First annual cost \\
\hline W & System power \\
\hline e & Electricity cost \\
\hline $\mathrm{t}$ & Operation hours \\
\hline ASV & Annual salvage value \\
\hline AMC & Annual maintenance cost \\
\hline ARC & Annual current cost \\
\hline $\mathrm{AC}$ & Annual cost \\
\hline $\mathrm{C}$ & Cost per kilogram \\
\hline US\$ & US dollar \\
\hline
\end{tabular}




\section{References}

1. Shafii, M.B.; Jafargholi, H.; Faegh, M. Experimental investigation of heat recovery in a humidification-dehumidification desalination system via a heat pump. Desalination 2018, 437, 81-88. [CrossRef]

2. Ullah, I.; Rasul, M.G. Recent developments in solar thermal desalination technologies: A review. Energies 2019, 12, 119. [CrossRef]

3. Yıldırım, C.; Solmuş, İ. A parametric study on a humidification-dehumidification (HDH) desalination unit powered by solar air and water heaters. Energy Convers. Manag. 2014, 86, 568-575. [CrossRef]

4. Kang, H.; Wang, T.; Zheng, H. Comparative analysis of regenerative and air-extraction multi-stage humidification-dehumidification desalination system using pinch technology. Desalination 2016, 385, 158-166. [CrossRef]

5. Chiranjeevi, C.; Srinivas, T. Augmented desalination with cooling integration. Int. J. Refrig. 2017, 80, $106-119$. [CrossRef]

6. Giwa, A.; Akther, N.; Al Housani, A.; Haris, S.; Hasan, S.W. Recent advances in humidification dehumidification $(\mathrm{HDH})$ desalination processes: Improved designs and productivity. Renew. Sustain. Energy Rev. 2016, 57, 929-944. [CrossRef]

7. Abdelmoez, W.; Mahmoud, M.S.; Farrag, T.E. Water desalination using humidification/dehumidification $(\mathrm{HDH})$ technique powered by solar energy: A detailed review. Desalin. Water Treat. 2014, 52, 4622-4640. [CrossRef]

8. Sathyamurthy, R.; El-Agouz, S.A.; Nagarajan, P.K.; Subramani, J.; Arunkumar, T.; Mageshbabu, D.; Madhu, B.; Bharathwaaj, R.; Prakash, N. A review of integrating solar collectors to solar still. Renew. Sustain. Energy Rev. 2017, 77, 1069-1097. [CrossRef]

9. Zamen, M.; Amidpour, M.; Soufari, S.M. Cost optimization of a solar humidification-dehumidification desalination unit using mathematical programming. Desalination 2009, 239, 92-99. [CrossRef]

10. Liu, Z.H.; Guan, H.Y.; Wang, G.S. Performance optimization study on an integrated solar desalination system with multi-stage evaporation/heat recovery processes. Energy 2014, 76, 1001-1010. [CrossRef]

11. Zubair, M.I.; Al-Sulaiman, F.A.; Antar, M.A.; Al-Dini, S.A.; Ibrahim, N.I. Performance and cost assessment of solar driven humidification dehumidification desalination system. Energy Convers. Manag. 2017, 132, 28-39. [CrossRef]

12. Xu, H.; Dai, Y.J. Parameter analysis and optimization of a two-stage solar assisted heat pump desalination system based on humidification-dehumidification process. Sol. Energy 2019, 187, 185-198. [CrossRef]

13. He, W.F.; Han, D.; Ji, C. Investigation on humidification dehumidification desalination system coupled with heat pump. Desalination 2018, 436, 152-160. [CrossRef]

14. Faegh, M.; Shafii, M.B. Performance evaluation of a novel compact humidification-dehumidification desalination system coupled with a heat pump for design and off-design conditions. Energy Convers. Manag. 2019, 194, 160-172. [CrossRef]

15. Wu, G.; Zheng, H.F.; Wang, F.; Chang, Z.-H. Parametric study of a tandem desalination system based on humidification-dehumidification process with 3-stage heat recovery. Appl. Therm. Eng. 2017, 112, $190-200$. [CrossRef]

16. Lawal, D.U.; Antar, M.A.; Khalifa, A.; Zubair, S.M.; Al-Sulaiman, F. Experımental investigation of heat pump driven humidification-dehumidification desalination system for water desalination and space conditioning. Desalination 2020, 475, 114199. [CrossRef]

17. Zhang, Y.; Zhu, C.; Zhang, H.; Zheng, W.; You, S.; Zhen, Y. Experimental study of a humidification-dehumidification desalination system with heat pump unit. Desalination 2018, 442, $108-117$. [CrossRef]

18. El-Agouz, S.A. A new process of desalination by air passing through seawater based on humidification-dehumidification process. Energy 2010, 35, 5108-5114. [CrossRef]

19. Faegh, M.; Behnam, P.; Shafii, M.B. A review on recent advances in humidification-dehumidification $(\mathrm{HDH})$ desalination systems integrated with refrigeration, power and desalination technologies. Energy Convers. Manag. 2019, 196, 1002-1036. [CrossRef]

20. Mohamed AS, A.; Ahmed, M.S.; Shahdy, A.G. Theoretical and experimental study of a seawater desalination system based on humidification-dehumidification technique. Renew. Energy 2020, 152, 823-834. [CrossRef] 
21. Zhao, Y.; Zheng, H.; Liang, S.; Zhang, N.; Ma, X.L. Experimental research on four-stage cross flow humidification dehumidification (HDH) solar desalination system with direct contact dehumidifiers. Desalination 2019, 467, 147-157. [CrossRef]

22. Rahimi-Ahar, Z.; Hatamipour, M.S.; Ghalavand, Y. Experimental investigation of a solar vacuum humidification-dehumidification (VHDH) desalination system. Desalination 2018, 437, 73-80. [CrossRef]

23. Behnam, P.; Shafii, M.B. Examination of a solar desalination system equipped with an air bubble column humidifier, evacuated duct collectors and thermosyphon heat pipes. Desalination 2016, 397, 30-37. [CrossRef]

24. Ayati, E.; Rahimi-Ahar, Z.; Hatamipour, M.S.; Ghalavand, Y. Water productivity enhancement in variable pressure humidification dehumidification $(\mathrm{HDH})$ desalination systems using heat pump. Appl. Therm. Eng. 2019, 160, 114114. [CrossRef]

(C) 2020 by the authors. Licensee MDPI, Basel, Switzerland. This article is an open access article distributed under the terms and conditions of the Creative Commons Attribution (CC BY) license (http://creativecommons.org/licenses/by/4.0/). 